\title{
O CESARZOWYCH CESARSTWA ŁACIŃSKIEGO (1204-1261) (2). AGNIESZKA Z MONTFERRAT I (MARIA?) NIEZNANA CÓRKA CARA KAŁOJANA
}

\author{
ZDZISEAW PENTEK
}

\begin{abstract}
On Empresses of the Latin Empire (1204-1261). Agnes of Montferrat and (Maria?) the unknown daughter of Tsar Kaloyan. The article is the second part of the series 'On Empresses of the Latin Empire (12041261)'. This one is dedicated to Agnes of Montferrat and the second wife (probably Maria) of Emperor Henry of Flanders, and the daughter of Tsar Kaloyan. The text presents their fate and the political significance of Henry's marriages. Analyses devoted to both Henry's wives show how scarce source material is available to a historian who tries to write anything about them. The childlessness of Henry of Flanders influenced the fate of the Latin Empire. I would also like to point out that Henry went beyond the current scheme of marrying women from his own cultural circle.
\end{abstract}

StReszCZENIE. Artykuł jest drugą częścią cyklu 'O cesarzowych Cesarstwa Łacińskiego (1204-1261)'. Ten jest poświęcony Agnieszce z Montferrat i drugiej żonie (prawdopodobnie Marii) cesarza Henryka z Flandrii, a córce cara Kołojana. W tekście przybliżono ich losy oraz polityczne znaczenie małżeństw Henryka. Analizy poświęcone obu żonom Henryka pokazują, jak znikomym materiałem źródłowym dysponuje historyk usiłujący cokolwiek o nich napisać. Bezpotomność Henryka z Flandrii wywarła wpływ na losy Cesarstwa Łacińskiego. Zwracam też uwagę, że Henryk wyszedł poza dotychczasowy schemat poślubiania kobiet z własnego kręgu kulturowego.

Author: Zdzisław Pentek, Uniwersytet im. Adama Mickiewicza w Poznaniu, Wydział Historii, ul. Uniwersytetu Poznańskiego 7, 61-614 Poznań, zp26@amu.edu.pl, ORCID iD: https://orcid.org/0000-0001-6500-6559

Keywords: Agnes of Montferrat, second wife of emperor Henry of Flanders, Latin Empire

Słowa kluczowe: Agnieszka z Monferrat, druga żona cesarza Henryka z Flandrii, Cesarstwo Łacińskie

Balcanica Posnaniensia. Acta et studia, XXVIII/2, Poznań 2021, Wydawnictwo Wydziału Historii UAM, pp. 31 40, ISBN 978-83-66355-84-2, ISSN 0239-4278. Polish text with summaries in English and Polish

doi.org/10.14746/bp.2021.28.18

Pierwszego władcę Cesarstwa Łacińskiego Baldwina I (1204-1205) - który wpadł do niewoli bułgarskiego cara Kałojana w bitwie pod Adrianopolem 14 kwietnia 1205 roku - baronowie jego domeny uznali za nieżyjącego ostatecznie w połowie 1206 roku ${ }^{1}$. W czasie interregnum, funkcję regenta Cesarstwa - całkiem sprawnie - peł-

1 Geoffroy de Villehardouin, La conquête de Constantinople, editée et traduite par Edmond Faral..., t. 1-2, Paris 1938-1939, § 360; Nicetae Choniatae Historia, red. J. L. van Dieten, Berolini-Novi Eboraci 
nił Henryk, brat Baldwina, dając nadzieję, że będzie on, co najmniej godnym następcą poprzednika. I tak, decyzją łacińskich baronów przy aprobacie Wenecjan² ${ }^{2}$ Henryk został podniesiony na tron w Konstantynopolu, a jego koronacja odbyła się 20 sierpnia 1206 roku, w trakcie permanentnej wojny z Bułgarią ${ }^{3}$. Była to jednak koronacja kawalera, gdyż Henryk nie posiadał małżonki. Ten stan należało prędko zmienić dla dobra młodego Cesarstwa, a na Henryku zaciążył obowiązek zagwarantowania dziedzica. Zatem, mając na uwadze powyższy tytuł, moja uwaga będzie skierowana na związki matrymonialne Henryka. Urodził się on w przedziale lat 1174-1178 w Valenciennes, a skoro był bratem Baldwina I, to jego genealogia jest identyczna ${ }^{4}$. Zapewne wkrótce po koronacji cesarskiej Henryka (a może i wcześniej), rozpoczął się proces poszukiwań odpowiedniej kandydatki, tak pod względem pozycji, jak i przydatności politycznej. Kronikarz Geoffroy z Villehardouin donosił w drugiej połowie 1206 roku o przybyciu do obozu cesarza w trackim Didimoticho ( $\tau$ ò $\Delta 1 \delta v \mu o ́ \tau \varepsilon \chi \propto v)$ Ottona de la Roche (zm. 1234 lub 1235), który oznajmił Henrykowi, że markiz Bonifacy zgodził się przyjąć propozycję poślubienia jego córki - Agnieszki z Montfferat. Ta zaś, na wezwanie ojca, przybyła z Lombardii do Salonik. Cesarz słysząc słowa posła, potwierdził swoje zamiary poślubienia nieznanej sobie kobiety:

Lors vint en l'ost un bers le marchis Boniface de Monferrat en messages, qui Othes de la Roche avoit non. Et parla d'un mariage, qui devant avoit esté porparlé, de la file Boniface de marchis de Monferrat et de l'empereor Henri: et aporta les novelles que la damme ere venue de Lombardie, et que ses peres i avoit envoié querre, et qu'ele ert a Salenique. Et fu asseürez li mariage d'une part et d'autre. Ensi s'en rala li messages a Salenique Othes de la Roche ${ }^{5}$.

Inicjatywa poślubienia Agnieszki wyszła rzecz jasna od Henryka, zapewne indagowanego przez baronów Cesarstwa, aby właśnie ją poślubić. Ale warto zadać sobie pytania: kim była Agnieszka z Montferrat i dlaczego poślubił ją Henryk? Nie wiadomo kiedy się urodziła. Była córką lombardzkiego markiza (od 1192 roku) Bonifacego z Montferrat ${ }^{6}$, wodza IV krucjaty, który wbrew swoim nadziejom nie został wybrany

1975, s. 616, wspominał, że cesarz został przewieziony do Tyrnowa; Genealogiae comitum Flandriae continuatio, Flandria generosa (Continuatio Gislenensis), red. L. Bethmann, MGH SS 9, Hannoverae 1861, s. 330.

2 Dowodem tego jest układ z 12 sierpnia 1206 roku potwierdzający Parititio Romaniae z podestą Wenecji w Konstantynopolu Marino Zeno; B. Hendrickx, Régestes des empereurs latins de Constantinople

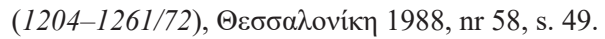

3 Villehardouin $\S 441$; Genealogiae comitum Flandriae continuatio, Flandria generosa, MGH SS 9 , s. 326.

${ }^{4}$ P. S. Noble, Henry of Constantinople (d. 1216), The Crusades. An Encyclopedia, t. 2, red. A. Murray, Santa Barbara 2006, s. 571; Z. Pentek, O cesarzowych Cesarstwa Lacińskiego (1204-1261) (1).

Maria hrabina Szampanii, „Balcanica Posnanienisa. Acta et studia” 2020, t. 27, s. 49.

5 Villehardouin $\S 450$; B. Hendrickx, Régestes..., nr 60, s. 50, Hendrickx uważa, że stało to się we wrześniu lub październiku 1206 roku.

${ }^{6}$ A. Goria, Bonifacio I, marchese di Monferrato, Dizionario Biografico degli Italiani, t. 12 (1971), za stroną https://www.treccani.it/enciclopedia/aleramo_(Dizionario-Biografico) [dostęp 03.08.2021]. Tam 
pierwszym cesarzem łacińskim. Zamiast tego, przypadła mu rola fundatora Królestwa Salonik. Dziadkiem ojczystym Agnieszki był Wilhelm V z Monferrat (zm. 1191), a babką Judyta z Babenbergu (1115/20-1178). Matką Agnieszki była — pierwsza żona markiza - Helena del Bosco (Elena di Busca) (ok. 1151-1210) poślubiona przez markiza około 1170 roku. Natomiast jej dziadkiem macierzystym był Anselmo, markiz Bosco. Należała więc do rodu rycerskiego Aleramitów, którego początki sięgają X wieku ${ }^{7}$. Starszym bratem Agnieszki był Wilhelm VI (Guglielmo) markiz Montferrat (ok. 1173-1226), który po śmierci ojca został również tytularnym królem w Salonikach. Jej siostrą była Beatrice — prawdopodobnie starsza od Agnieszki która została drugą żoną Henryka II del Carretto (1165-1231), markiza Savony ${ }^{8}$. Niestety, nic nie wiadomo na temat dzieciństwa i wczesnych losów Agnieszki aż do 1206 roku. Na plany małżeńskie Henryka należy spojrzeć też pod kątem pewnej legitymizacji jego władzy. Chodziło o uwiarygodnienie cesarza wśród ludności greckiej. Otóż Henryk wchodząc w związek z rodziną z Montferrat, stawał się powinowatym bizantyńskich Komnenów i Angelosów, a jego potencjalni potomkowie byliby ich krewnymi. Było to możliwe dzięki związkom braci Bonifacego - Rajnera (1162-1183) oraz Konrada (1145-1192). Rajner poślubił w lutym 1180 roku Marię Komnenę (1152-1182), córkę imperatora Manuela I, Konrad natomiast w 1187 roku poślubił Teodorę Angelinę (1160-?), siostrę cesarza Izaaka II Angelosa (1185-1195) i Izabelli Andegaweńskiej ${ }^{10}$. Również przyszły teść Henryka, już w 1205 roku chcąc m.in. budować pozytywny wizerunek wśród Greków, poślubił wdowę po Izaaku II Angelosie - Małgorzatę (1175-1223), córkę Béli III, króla Węgier. Małżeństwo

obszerna literatura.

7 Termin 'Aleramici' wywodzi się od założyciela dynastii — markiza Montferrat - Aleramo (zm. 991), który otrzymał ten tytuł wraz z córką Gerbergą w roku 958 od króla Berengara II (950-961); obszerny artykuł biograficzny — F. Cognasso, Alaramo, Dizionario Biografico degli Italiani, t. 2 (1960), za stroną https://www.treccani.it/enciclopedia/aleramo_(Dizionario-Biografico) [dostęp 03.08.2021]: R. Merlone, Prosopografica aleramica (secolo X e prima metà del XI), „Bolletino storico-bibliografico subalpino", 1993, t. 81, s. 451-586; R. Molinari, La Marca Aleramica. Storia di una regione mancata, Baldissero d'Alba 2008.

8 J. Brichieri Colombo, Tabulae genealogicae gentis Carrettensis et Marchionum Savonnae Finarri Clavexanae etc manuductionem praemisit totumque opus accuravit Joannes Bricherius Columbus, Ex Typographia Kaliwodiana, Vindobonae 1741, s. 26, 30nn, 41 i tablice genealogiczne (18); G. Nuti, Del Carretto, Enrico, marchese di Savona, Dizionario Biografico degli Italiani, t. 36 (1988), za stroną https:// www.treccani.it/enciclopedia/aleramo_(Dizionario-Biografico) [dostęp 03.08.2021].

9 Nicetae Choniatae Historia, red. J. L. van Dieten, Berolini-Novi Eboraci 1975, s. 260; Willelmi Tyresis Archiepiscopi Chronicon, Édition critique par R. B. C. Huygens. Identification des sources historiques et détermination des dates par H. E. Mayer et G. Rösch, Tvrnholti MCMLXXXVI, 22. 4, 42-54.

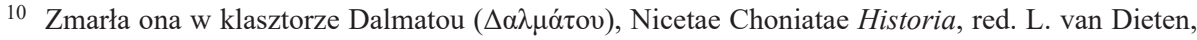

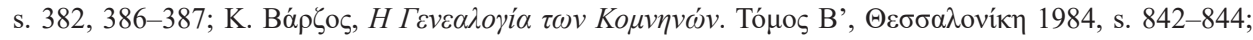
Ch. Brand, Byzantium confronts the West, Cambridge Mass. 1968, s. 80-82; Th. Ilgen, Konrad, Markgraf von Montferrat, Marburg 1890, s. 65-67; L. Usseglio, I Marchesi di Monferrato in Italia ed in Oriente durante i secoli XII e XIII, editi postumi a cura di C. Patrucco, Milano 1926, s. 153-156; W. Haberstumpf, Dinastie europee nel Mediterraneo orientale. I Monferrato e i Savoia nei secoli XII-XV, Torino 1995, s. $43,51,54-55$. 
miało też zamknąć wszelkie rozdźwięki pomiędzy zawiedzionym oraz rozczarowanym Bonifacym a Henrykiem. Potomkowie Henryka i Agnieszki mieli być gwarantami współpracy. A w konsekwencji międzynarodowej, ślub Henryka i Agnieszki był przypieczętowaniem politycznego sojuszu pomiędzy cesarzem a władcą Salonik skierowanego przeciw bułgarskiemu carowi Kałojanowi (1197-1207) ${ }^{11}$.

Po Bożym Narodzeniu 1206 roku do Konstantynopola przybyli nieznani nam wysłannicy Bonifacego i oznajmili, że markiz wysłał galerą swą córkę do Enez. W odpowiedzi na te działania, Henryk skierował swoich znamienitych posłów w osobach marszałka Romanii Geoffroya z Villehardouin i Emiliana z Brabancji, by odszukali Agnieszkę w Enez oraz sprowadzili ją do stolicy ${ }^{12}$ :

Endementiers fu tant del tens passé que li Noël fu passé. Lors vindrent li message le marchis a l'empereor in Costantinoble, et li distrent de par le marchis que il avoit envoié sa file en galies a la cité d'Aaimes. Et lors envoia l'empereres Henris Joffroi le mareschal de Romenie et de Champaigne et Milon de Braibant por querre de dame. Et chevauchierent par lor jorness tant que il vindrent a la cité d'Aines.

Wreszcie mamy pierwszą charakterystykę Agnieszki, którą spotkali w Enez (Aĩvo ) $^{\text {) }}$ Villehardouin i jego kompan Emilian z Brabancji: Et troverent la damme, qui mult ere et bone et bele... ${ }^{13}$. Była to więc piękna młoda kobieta, którą — w sumie — w dość skromnej asyście zabrano do Konstantynopola. Jedynie fragmenty zaślubin i wesela młodej pary opisał świadek tych wydarzeń, Villehardouin:

Et l'esposa l'empereres Henris au mostier Sainte Sophye, le diemenche aprés la feste madame sainte Marie Candelor, a grant joie et a grant honor; et porterent corone ambedui; et furent les noces haltes et planieres el palais de Bochelion. Ensi fu fait li mariages de l'empereor e de la file le marchis Bonface, qui Agnés l'empereris avoit nom, com vos avés oï ${ }^{14}$.

Dnia 4 lutego 1207 roku doszło ceremonii zaślubin w świątyni Mądrości Bożej i z dużym rozmachem urządzonego wesela w pałacu Bukoleon. Zwraca tu uwagę fragment uroczystości: porterent corone ambedui... Mamy potwierdzenie, że doszło do pierwszej koronacji cesarskiej kobiety w łacińskim państwie nad Bosforem. Natomiast nie jest jasne czy postąpiono zgodnie ze zwyczajem bizantyńskim i Henryk nałożył koronę cesarską na skronie małżonki. Nie wiemy nic o posagu panny młodej. Wydaje się też uzasadnione podejrzenie, że na ślubie cesarzowej Agnieszki nie był obecny jej ojciec. O tym źródła milczą. Nie wiemy również, jak wyglądał dwór, najbliższe otoczenie nowej cesarzowej. Czy był on oparty wyłącznie na łacińskich damach mieszkają-

11 M. D. Sturdza, Dictionnaire Historique et Généalogique des Grandes Familles de Grèce, d'Albanie et de Constantinople, Paris 1999, s. 542.

12 Villehardouin § 457; B. Hendrickx, Régestes..., nr 65, s. 53.

13 Villehardouin $\S 458$.

14 Villehardouin $\S 458$. 
cych w Konstantynopolu czy też towarzyszyły jej dworzanie jeszcze z Montferrat lub Enez. Ta druga ewentualność wydaje się być całkiem prawdopodobna.

Od chwili koronacji — na kilka miesięcy — cesarzowa znikła ze źródeł. Wreszcie, w lipcu lub raczej sierpniu 1207 roku doszło do spotkania Henryka ze swoim teściem Bonifacym. Miało to miejsce na równinie opodal miejscowości Capesale, jak napisał Villehardouin, tzn. w Kypseli (grecka'Y $\psi \alpha \lambda \alpha$, obecnie tur. İpsala), około $25 \mathrm{~km}$ na południowy zachód od Adrianopola. Wówczas Bonifacy miał zapytać cesarza Henryka o swą córkę: Et li marchis demanda novelles de sa file l'empereries Agnés; et on li dist que ele ere grosse d'anfant, et li en fi mult liez et joianz ${ }^{15}$. Niewątpliwie wiadomość o ciąży Agnieszki była pomyślna przede wszystkim dla przyszłości Cesarstwa. Musiała rzecz jasna uradować Bonifacego z racji skutków politycznych tego wydarzenia, a także jako przyszłego dziadka. Jednak po śmierci Bonifacego, być może 4 września 1207 roku, Villehardouin zaniechał kontynuacji swego dzieła i wiarygodne źródło narracyjne przestało dostarczać nam informacji ${ }^{16}$. W związku z tym, na podstawie kroniki Villehardouina nie uzyskujemy odpowiedzi, jak się zakończyła ciąża cesarzowej, ale - ex silentio - dowiadujemy się, że rozwiązanie nie nastąpiło na początku września 1207 roku. Niestety, należy przyjąć, że Agnieszka zmarła w połogu, podobnie jak urodzone przez nią dziecko. Nie wiadomo, kiedy się to stało, ani gdzie cesarzowa została pochowana. Zatem, druga cesarzowa łacińska cieszyła się nieomal równie krótko, jak pierwsza, zdrowiem i życiem. Było to małżeństwo polityczne, które z jednej strony miało wygasić animozje pomiędzy przywódcami IV krucjaty i zjednoczyć siły łacinników przeciwko Kałojanowi. Poza tymi aspektami, trudno doszukiwać się innych wątków łączących Henryka i Agnieszkę. W efekcie, problem dziedzictwa tronu nie został rozwiązany i dla zapewnienia przyszłości dynastycznej Cesarstwa oznaczało to jedno - Henryk winien ponownie się ożenić.

Uważany za kontynuatora dzieła Villehardouina, kronikarz Henryk z Valenciennes - na dobrą sprawę — rozpoczyna swój przekaz od 25 maja 1208 roku $^{17}$. Ani przed tą datą ani po niej, dziejopis ani słowem nie wspomniał o pierwszej żonie i potomku cesarza. Wnioski mogą być takie, że Agnieszka już nie żyła, a recepcja cesarzowej była znikoma lub żadna. W październiku lub listopadzie 1208 roku Henryk z Valenciennes wspomniał o związku „Esclasa”, tj. Aleksego Sława z bezimienną córką cesarza Henryka ${ }^{18}$. O tym samym nadmienił również bizantyński dzie-

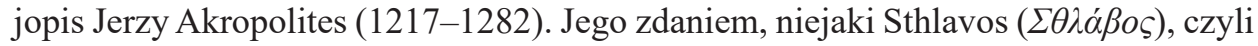
Aleksy Sław (zm. 1228) będący synem siostry cara Asena (1188-1196), pojął za żonę nieznaną nam z imienia córkę Henryka, którą urodziła mu bezimienna nałoż-

15 Villehardouin $\S 496$.

16 Villehardouin § 498-499. Datacja śmierci markiza jest oparta o A. Ceruti, Un codice del monasterio cistercense di Lucedio, „Archivio storico italiano”, 1881, t. 8, s. 378.

17 Henri de Valenciennes § 504: Il avint, chou dist Henris, a une Pentecouste, que li empereres ert a sejour en Constantinoble... Pierwsze trzy paragrafy kroniki są prologiem i nie można ich w żaden sposób datować.

18 Henri de Valenciennes § 555-557. 
nica $(\dot{\varepsilon} \kappa \pi \alpha \lambda \lambda \alpha \kappa \tilde{\eta} \varsigma)^{19}$. A więc i Akropolites potwierdził nieformalny związek cesarza. Zatem Henryk miał córkę z nieprawego łoża, być może urodzoną jeszcze przed poślubieniem Agnieszki z Montferrat lub wkrótce po jej śmierci. Skoro nieznane są imiona córki cesarza oraz jej matki, należy przypuszczać, iż fakt ten niebędący powodem do dumy Henryka, chciano wyprzeć ze zbiorowej pamięci. Gdyby była to córka Agnieszki i Henryka, to z pewnością zadbano by o utrwalenie jej imienia. Inna sprawa to kontekst polityczny tego małżeństwa, które definitywne lokował Aleksego Sława wśród wasali cesarza i przeciwników Bułgarii.

Z pobudek li tylko politycznych, Henryk wszedł w drugi związek małżeński z nieznaną z imienia córką cara Kałojana i Anny Kumanki ${ }^{20}$. Ta zaś, po śmierci pierwszego małżonka w 1207 roku poślubiła jego siostrzeńca, cara Boriła (1207-1218), legitymizując w ten sposób jego panowanie. Zdaniem Vasila Złatarskiego (1866-1935) imię córki Kałojana brzmiało Maria, jest to jednak pewna projekcja bułgarskiego uczonego $^{21}$. Niestety, badania nad przodkami jej rodziców okazują się, jak dotąd bezowocne, oprócz tego, że wywodziła się z rodu kumańskich bojarów ${ }^{22}$.

Kiedy urodziła się druga żona Henryka tego nie wiemy. Najpóźniejsza możliwa data jej urodzin to rok 1207, czyli data śmierci jej ojca. Możliwe jednak, że urodziła się jeszcze pod koniec XII wieku i osiągnęła już wiek sprawny do małżeństwa, który według ówczesnych pojęć wynosił dwanaście lat. W małżeństwach o charakterze politycznym często jednak wiek nie miał znaczenia i poślubiano nawet kilkuletnie

19 Georgii Acropolitae Opera recensuit Augustus Heisenberg, editionem anni MCMIII, correctiorem curavit Peter Wirth, vol. 1, Stutgardiae 1978, rozdz. 24, s. 38-39; dziejopis dodawał, że cesarz ob-

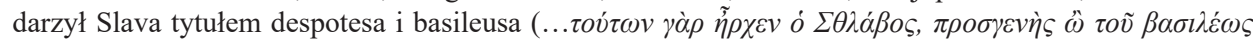

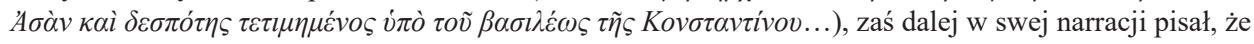
nie uległ presji okolicznych władców, może więc i samemu Henrykowi, rozdz. 24, s. 39; И. Божилов, Фамилията на Асеневци (1186-1460). Генеалогия и просопография, София 1985, s. 95-98.

20 Sprawa wyjaśnienia imienia żony Kałojana i Boriła zdaje się została rozwiązana wraz z nowym odczytem zabytku bułgarskiego z okresu II Państwa Bułgarskiego — „Борилов Синодик”, gdzie mowa: 118. [На] изарица Ана, наречена Анисия, и на другата Ана, благочестива цุарица на христолюбивия изар Асен, и на Ирина, благочестивата майка на христолюбивия ияар Михаил, наречена в монашески образ Ксения, вечна памет, Борилов Синодик, http://ald-bg.narod.ru/biblioteka/bg_srednovekovie/borilov_sinodik/borilov_sinodik.htm [dostęp 03.08.2021]; И. Божилов, Фамилията, София 1985, s. 8788; И. Божилов, А. Тотоманова, Ив. Билярски, Борилов синодик. Издание и превод, София 2010, карта 34a, s. 163, wersy 6-10; А. Тотоманова, Синодик ияаря Борила в сборнике Палаузова (НБКМ № 289), [w:] XXI ежегодная богословская конференция. Церковно-историческия исследования в контексте современной науки, Москва 2011, s. 165-171; А. М. Totomanova, The Synodikon of Orthodoxy in Medieval Bulgaria, „Studia Ceranea” 2017, t. 7, s. 169-227.

21 В. Златарски, История на българската държава презъ срґднитъ въкове. Томъ III. Второ българско царство. България при Асъневци (1187-1280), София 1940, s. 309; И. Божилов, Фамилията, s. 93-94, nie aprobuje imienia zaproponowanego przez V. Złatarskiego; П. Павлов, За ролята на куманите в българската военна история (1186-1241), „Военноисторически сборник” 1990, t. 59, s. 14-23.

22 И. Божилов, Фамилията, s. 58, 74, 87; П. Павлов, За ролята, „Военноисторически сборник” 1990, t. 59, s. 21. 
dziewczynki. Wedle słów Roberta z Clari była ona piękna ${ }^{23}$, mimo to Henryk podobno się wykręcał od tego małżeństwa: ...Et li empereres respondi ke femme de si bas parage ne prendroit il ja ${ }^{24}$. Zgodził się na poślubienie carówny bułgarskiej dopiero na skutek presji baronów: ...Et tant parlerent li baron que li empereres $i$ envoia deus chevaliers haus hommés... ${ }^{25}$. Wysłanie poselstwa na dwór Boriła okazało się ryzykowne, jak relacjonował pikardyjski dziejopis Robert. Car świadomy sytuacji militarnej i politycznej Bułgarii, postanowił wysłać swą pasierbicę na dwór w Konstantynopolu, aby w ten sposób zakończyć niepomyślną dla kraju wojnę z Cesarstwem Łacińskim: ...Burus que li leur respondi qui il envoieroit volentiers se fille a l'empereeur ${ }^{26}$. Władca Bułgarii wyposażył Marię adekwatnie do jej pochodzenia, jej posag był imponujący, co odnotował Robert z Clari:

Adonques si fist atorner Burus li rois se fille molt rikement et molt noblement, et assés gent avec lui; si l'envoia a l'empereeur, et li fist baillier soisante sommiers tous carkiés d'avoir et d'or et d'argent et de dras de soie et de rikes joiaus; ne n'i avoit sommier qui ne fust couvers d'un vermel samit, qui si estoit lons qu'il trainoit bien set piés ou uit a cascun par derriere, ne ja tant n'alaissent par boe ne par laides voies que ja en fust nus des samis escorchiés, tout par cointise et par nobleche ${ }^{27}$.

Opis ceremonii zaślubin nie został uwzględniony przez Roberta, oprócz krótkiej wzmianki o powitaniu Marii przez Henryka i jej ślubie z cesarzem: Quant li empereres seut que le demisele venoit, si ala encontre lui, et li baron avec lui, et si en fist molt grant feste de lui et de se gent, et puis aprés si l'espousa l'empereres ${ }^{28}$.

Datacja ślubu nie jest rozstrzygnięta. Za Benjaminem Hendrickxem (*1939) wypada ją przyjąć na czas pomiędzy 5 sierpnia 1213 a 4 sierpnia 1214 roku $^{29}$. Oczywistym jest, że wraz z Marią do Konstantynopola udała się bułgarska świta, a wśród nich były zapewne dwórki i dworzanie nowej cesarzowej. Ale nic o tym nie wiadomo. Również o dalszych poczynaniach Marii w Konstantynopolu nic nie wiadomo. Brak śladów jej działalności daje pole do przypuszczeń, że jej rola była marginalna, z racji tego, że

23 Robert de Clari § CXVI.

24 Robert de Clari § CXVI; F. van Tricht, The Latin Renovatio of Byzantium. The Empire of Constantinople (1204-1228), thum. Peter Longbottom, Leiden-Boston 2011, s. 393, przypuszcza, że Henryk wchodząc w związek małżeński z Marią, miał aspiracje uniwersalistyczne, które zakładały podporządkowanie Bułgarii, a może nawet panowanie nad tymi ziemiami, gdy tylko urodzi się męski potomek cesarskiej pary. W przeciwieństwie do F. van Trichta sądzę, że Henryk był na tyle pragmatyczny i świadomy, jak nikłymi siłami dysponuje i dlatego próby ponownego podporządkowania lub zwasalizowania Bułgarii nie wchodziły w grę. Działania cesarza miały przyczynić się spacyfikowania regionu drogą politycznych małżeństw oraz powstrzymania w 1213 roku zapędów — i tak mniej agresywnego od Kałojana Boriła.

25 Robert de Clari § CXVI.

26 Robert de Clari § CXVI.

27 Robert de Clari § CXVII.

28 Robert de Clari § CXVIII.

29 Ernoul, Chronique d'Ernoul et de Bernard le Trésorier, red. Louis de Mas-Latrie, Paris 1871, s. 391 również nie datuje tego wydarzenia: Li empereres Henris fist pais as Blas et prist le fille l'empereur de Blakie...; B. Hendrickx, Régestes..., nry 134-135, s. 93-94; F. van Tricht, s. 391-392. 
była dzieckiem lub nawet celowo marginalizowana ${ }^{30}$. Nie wiemy, czy Henryk nadal traktował ją z dystansem lub nawet $\mathrm{z}$ lekką pogardą. A tak miało być wcześniej, gdy przedstawiono ją jako kandydatkę na małżonkę, o czym pisał Robert z Clari. Cesarz ponoć deklarował, że nigdy nie poślubi osoby tak niskiego urodzenia ${ }^{31}$. W związku z tym, kolejny raz nic nie wiadomo o traktowaniu przez Henryka cesarzowej po ślubie, gdy porozumienie było utrudnione z tej racji, iż posługiwali się różnymi językami. Nie ma śladów źródłowych, aby para doczekała się potomstwa. Henryk, niespodziewanie zmarł 11 czerwca 1216 roku w Salonikach ${ }^{32}$. Zdaniem dawniejszej historiografii maczać ręce w tym miała jego żona, która otruła męża ${ }^{33}$. Nasuwa się w związku z tym szereg pytań. Czy to może być w ogóle prawdą? Dlaczego doszło do tego podczas wizyty cesarza w Salonikach, a nie np. w Konstantynopolu? ${ }^{34} \mathrm{Czy}$ w ten sposób ewentualna 'trucicielka' chciała odwrócić uwagę od siebie, a rzucić podejrzenia na środowiska Salonik? Kto mógł cokolwiek zyskać na śmierci Henryka? Czy mogła to być zemsta córki za śmierć ojca Kałojana, którą de facto zadali mu jego podwładni? Czy był to wynik małżeńskich waśni, które popchnęły żonę do zabójstwa męża? Rozpatrując wątek zysków po śmierci Henryka, należy zauważyć, że uradowali się wszyscy jego oponenci polityczni, z Bułgarią na czele. Car Borił pozbywał się dzięki śmierci cesarza, niezręcznego gorsetu politycznego jaki zawiązał mu Henryk swoimi wcześniejszymi sukcesami. Mimo wszystko, są to pytania, na które nie można udzielić jakiejkolwiek wiążącej odpowiedzi, a wnioski to czysta spekulacja. Odpowiedzi zdaje się nie poznamy. Od śmierci Henryka jego druga małżonka nie pojawiła się na kartach historii, co dowodzi, że nie upatrywano w niej samotnie władającej. Być może zbiegła do Bułgarii, może została uwięziona lub nawet zgładzona w Konstantynopolu. Reasumując, nie wiadomo, co się z nią stało, kiedy i w jakich

30 Widoczny jest brak imienia Marii w źródłach sfragistycznych i numizmatycznych.

31 Robert de Clari § CXVI.

32 Robert de Clari § CXIX; Ernoul, s. 391; L'Estoire de Eracles Empereur et la conqueste de la terre d'Outremer (suite), RHC, HOc. 2, s. 289-290, podaje, choć nie wiadomo czy było to adekwatne do sytuacji, o powrocie rycerzy i podkomendnych Henryka do Konstantynopola, celem jego obrony. Jednak żadne ze źródeł nic nie wspomina o jego żonie i czy towarzyszyła mu w Salonikach.

33 Chronica monasterii sancti Bertini auctore Iohanne Longo de Ipra, red. O. Holder-Egger MGH SS 25, Hannoverae 1880, s. 832: Henricus imperator Constantinopolitanus... ab uxore propria intoxicatus obiit...; inne źródło nie potwierdza tego - Reinerus, Annales Sancti Jacobi Leodiensis, red. G. H. Pertz, MGH SS 16, Hannoverae 1858, s. 675: Eodem anno non multo post obiit Henricus imperator Constantinopolitanus qui Greciam post fratrem suum Balduinum feliciter et efficaciter rexit de cuius morte tota christianitas doluit quia signatis nostris multa promiserat et se iturum in virtute armorum in negotium orientalis ecclesie predixerat...; E. Gerland, Geschichte der Frankenherrschaft in Griechenland von dr. Ernst Gerland. I Band. Geschichte des lateinischen Kaiserreiches von Konstantinopel. Erster Teil: Geschichte der Kaiser Balduin I. und Heinrich 1204-1216. Unter Benutzung eines Manuskriptes von Carl Hopf und mit Unterstützung des Königl. Preuss. Ministeriums der geistlichen, Unterrichts- und Medizinal-Angelegenheiten, Homburg v[on] d[er] Höhe 1905, s. 250; J. Longnon, L'Empire Latin de Constantinople et la Principauté de Morée, Paris 1949, s. 150-151; niewiele o bułgarskiej władczyni także w А. Данчева-Василева, България и латинската илперия 1204-1261, София 1985, zwłaszcza s. 111; В. Гюзелев, Папството и българите през Средновековието, Пловдив 2009, s. 187.

${ }^{34}$ Nie wiadomo, czy Henryk sam udał się do Salonik czy w towarzystwie małżonki. 
okolicznościach zmarła oraz gdzie została pochowana trzecia cesarzowa Cesarstwa Łacińskiego.

Próbując czynić próbę podsumowania dla wspomnianych małżonek Henryka, to należy zwrócić uwagę, że znajdując się w nowych realiach politycznych wyszedł on poza dotychczasowy schemat poślubiania kobiet tylko z własnego kręgu kulturowego. Był on pod tym względem wyjątkiem, ponieważ żadna z późniejszych cesarzowych łacińskich nie wywodziła się ani z dawnego Bizancjum ani z Bułgarii. Doraźna korzyść polityczna stanowiła jedyny bodziec obu jego małżeństw, co było zjawiskiem typowym dla władców nie tylko średniowiecznych. Oczywiście, pożądani byli potomkowie pary cesarskiej, ale tych Henryk nie doczekał, a przynajmniej nic o ich istnieniu nie wiadomo.

\section{BIBLIOGRAFIA}

\section{Źródla}

Chronica monasterii sancti Bertini auctore Iohanne Longo de Ipra, red. O. Holder-Egger MGH SS 25, Hannoverae 1880.

Ernoul, Chronique d'Ernoul et de Bernard le Trésorier, red. Louis de Mas-Latrie, Paris 1871.

L'Estoire de Eracles Empereur et la conqueste de la terre d'Outremer (suite), „Recueil des Historiens des Croisades”, „Historiens Occidentuax” [RHC Hoc.], Paris 1859, t. 2.

Flandria generosa (Continuatio Gislenensis), red. Ludwig Bethmann, MGH SS 9, Hannoverae 1861.

Geoffroy de Villehardouin, La conquête de Constantinople, red. i thum. Edmond Faral..., t. 1-2, Paris 1938-1939.

Georgii Acropolitae Opera recensuit Augustus Heisenberg, editionem anni MCMIII, correctiorem curavit Peter Wirth, t. 1, Stutgardiae 1978.

Henri de Valenciennes, Histoire de l'empereur Henri de Constantinople publiée par Jean Longnon, Paris 1948.

Nicetae Choniatae, Historia, red. J. L. van Dieten, Berolini-Novi Eboraci 1975.

Reinerus, Annales Sancti Jacobi Leodiensis, red. G. H. Pertz, MGH SS 16, Hannoverae 1859.

Willelmi Tyresis Archiepiscopi Chronicon, Édition critique par R. B. C. Huygens. Identification des sources historiques et détermination des dates par H. E. Mayer et G. Rösch, Tvrnholti MCMLXXXVI.

\section{Opracowania}

Božilov I., Familijata na Asenevci (1186-1460). Genealogija i prosopografija, Sofija 1985 [Божилов И., Фамилията на Асеневии (1186-1460). Генеалогия и просопография, София 1985].

Božilov I., Totomanova A., Biljarski I., Borilov sinodik. Izdanie i prevod, Sofija 2010 [Божилов И., Тотоманова А., Билярски И., Борилов синодик. Издание и превод, София 2010].

Brand Ch., Byzantium confronts the West, Cambridge Mass. 1968.

Brichieri Colombo G. D., Tabulae genealogicae gentis Carrettensis, Vindobonae 1741.

Ceruti A., Un codice del monasterio cistercense di Lucedio, „Archivio storico italiano” 1881, t. 8, s. 378.

Cognasso F., Alaramo, [w:] Dizionario biografico degli Italiani, t. 2 (1960), https://www.treccani.it/enciclopedia/aleramo_(Dizionario-Biografico) [dostęp: 03.08.2021].

Dančeva-Vasileva A, Bălgarija i latinskata imperija 1204-1261, Sofija 1985 [Данчева-Василева А., България и латинската империя 1204-1261, София 1985].

Gerland E., Geschichte der Frankenherrschaft in Griechenland von dr. Ernst Gerland. I Band. Geschichte des lateinischen Kaiserreiches von Konstantinopel. Erster Teil: Geschichte der Kaiser Balduin I. und Heinrich 1204-1216. Unter Benutzung eines Manuskriptes von Carl Hopf und mit Unterstützung 
des Königl. Preuss. Ministeriums der geistlichen, Unterrichts- und Medizinal-Angelegenheiten, Homburg v[on] d[er] Höhe 1905.

Goria A., Bonifacio I, marchese di Monferrato, [w:] Dizionario biografico degli Italiani, t. 12 (1971), https://www.treccani.it/enciclopedia/aleramo_(Dizionario-Biografico) [dostęp: 03.08.2021].

Gjuzelev V., Papstvoto i bŭlgarite prez Srednovekovieto, Plovdiv 2009 [Гюзелев В., Папството и българите през Средновековието, Пловдив 2009].

Haberstumpf W., Dinastie europee nel Mediterraneo orientale. I Monferrato e i Savoia nei secoli XII$X V$, Torino 1995 .

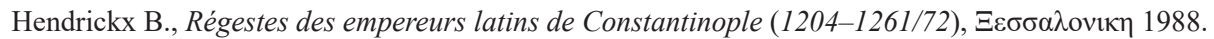

Ilgen T., Konrad, Markgraf von Montferrat, Marburg 1880.

Longnon J., L'Empire Latin de Constantinople et la Principauté de Morée, Paris 1949.

Merlone R., Prosopografica aleramica (secolo X e prima metà del XI), „Bolletino storico-bibliografico subalpino" 1993, t. 81, s. 451-586.

Molinari R., La Marca Aleramica. Storia di una regione mancata, Baldissero d'Alba 2008.

Noble P. S., Henry of Constantinople (d. 1216), [w:] The Crusades. An Encyclopedia, t. 2, red. A. Murray, Santa Barbara 2006.

Nuti G., Del Carretto, Enrico, marchese di Savona, [w:] Dizionario biografico degli Italiani, t. 36 (1988), https://www.treccani.it/enciclopedia/aleramo_(Dizionario-Biografico) [dostęp: 03.08.2021].

Pavlov P., Za roliata na kumanite v bălgarskata voenna istorija (1186-1241), Voennoistoričeski sbornik” 1990, t. 6, s. 14-23 [Павлов П., За ролята на куманите в българската военна история (11861241) „Военноисторически сборник” 1990, t. 6, s. 14-23].

Pentek Z., O cesarzowych Cesarstwa Łacińskiego (1204-1261) (1). Maria hrabina Szampanii, „Balcanica Posnanienisa. Acta et studia" 2020, t. 27, s. 47-56.

Sturdza M. D., Dictionnaire Historique et Généalogique des Grandes Familles de Grèce, d'Albanie et de Constantinople, Paris 1999.

Totomanova A., Sinodik carja Borila v sbornike Palauzova (NBKM № 289), [w:] XXI ežegodnaja bogoslovskaja konferencija. Cerkovno-istoričeskija issledovanija v kontekste sovremennoj nauki, Moskva 2011, s. 165-171 [Тотоманова А., Синодик ияаря Борила в сборнике Палаузова (НБКМ № 289), [w:] ХХІ ежегодная богословская конференция. Церковно-историческия исследования в контексте современной науки, Москва 2011, s. 165-171].

Totomanova A., The Synodikon of Orthodoxy in Medieval Bulgaria, „Studia Ceranea” 2017, t. 7, s. 169227.

Usseglio, L., I Marchesi di Monferrato in Italia ed in Oriente durante i secoli XII e XIII, red. C. Patrucco, Milano 1926.

Van Tricht F., The Latin Renovatio of Byzantium. The Empire of Constantinople (1204-1228), thum. Peter Longbottom, Leiden-Boston 2011.

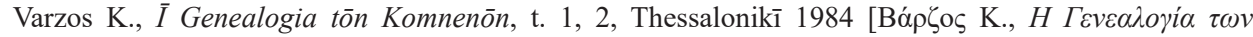

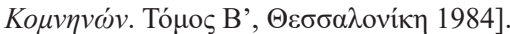

Złatarski V., Istorija na bălgarskata dăržava prez srednite vekove, t. 3 (Vtoro bălgarsko carstvo. Bălgarija pri Asenevci; 1187-1280, Sofija 1940 [Златарски В., История на българската държава през средните векове, t. 3 (Второ българско ияарство. България при Астневци; 1187-1280), София 1940]. 